\title{
Fishery-induced skin injuries in flatfish from the by-catch of shrimpers
}

\author{
Karin Lüdemann* \\ Institut für Hydrobiologie und Fischereiwissenschaft der Universität Hamburg, Elbelabor, Große Elbstraße 268, \\ D-22767 Hamburg, Germany
}

\begin{abstract}
Dab Limanda limanda L. from commercial shrimpers in the North Frisian Wadden Sea were examined for externally visible injuries during April to October 1991. Injuries are described macroscopically. The influence of catch conditions on the rate of injuries was subjected to statistical analysis. The number of fissures of the fins was positively correlated with fish length and catch volume, whereas the number of hemorrhages of the fins decreased significantly with increasing catch volume. Sorting on a traditional shaking sieve increased the rate of fissures and hemorrhages considerably. Wound healing experiments elucidated the process and duration of regeneration of typical fisheryinduced injuries. Experimentally induced skin injuries had closed up some hours after being made. They healed without scars; thus formerly suffered injuries cannot be quantified
\end{abstract}

\section{INTRODUCTION}

Fisheries seem to be an important source of skin injuries in fishes. This is mainly true for species without commercial interest such as dab, which are discarded immediately after the catch. According to Tiews (1990) the by-catch of dab in the German shrimp fishery amounted to 160.7 million individuals per year during the period 1982 to 1988. Mortality of flatfish from the by-catch strongly depends on fish size and catch processing conditions. The mean survival rate for dab is about $67 \%$ (Berghahn et al. 1992). Not considering the possibility of re-catch, about 108.3 million individuals of dab survive the catch procedure each year. Investigations by Kelle (1977) revealed that fish from the by-catch suffer a high rate of internal and external injuries.

The investigation of fishery-induced wounds covers a variety of aspects with each of them separately being well documented. Wound healing has been a question of interest since the end of last century (e.g. Loeb 1898; for recent study see e.g. Iger \& Abraham 1990).

\footnotetext{
- Present address: Institut für Hydrobiologie und Fischereiwissenschaft der Universität Hamburg, Zeiseweg 9 D-22765 Hamburg, Germany
}

Mortality rates of by-catch organisms have been investigated among others by Kelle (1976), Waltemath (1990), and Berghahn et al. (1992). Monitoring programs of fish diseases in the German Bight and southern part of the North Sea have been performed by Dethlefsen since 1979 (Dethlefsen et al. 1987) and in the Wadden Sea by Anders \& Möller (1991). Injuries caused by non-troll fishery (Bell \& Bagshaw 1985) and fish pumps (Grizzle et al. 1992) have been examined in order to solve applied problems of fisheries management. Injuries induced by commercial fishery to the by-catch organisms have not yet been studied, hence basic information was needed.

The objective of this study was to determine the kind and frequency of injuries occurring during the catch and sieving procedure in the shrimp fishery, and to look for ways of reducing damage to fish. In addition, the healing of typical fishery-induced injuries was studied in laboratory experiments.

\section{MATERIAL AND METHODS}

A total of $296 \mathrm{dab}$ from the by-catch of commercial shrimpers in the North Frisian Wadden Sea (Fig. 1) were examined. The dab were separated immediately 


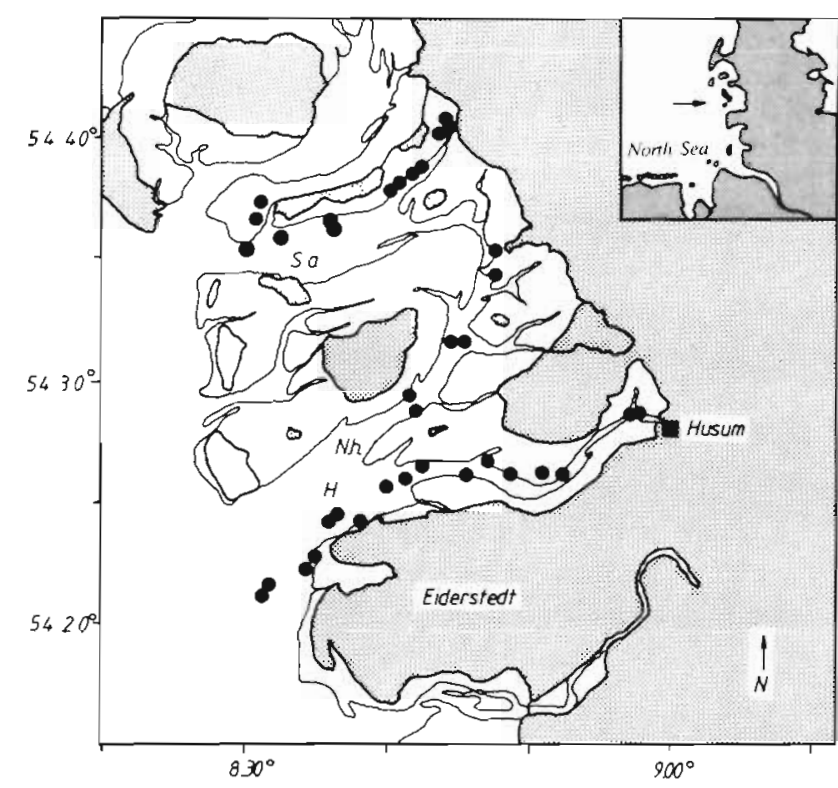

Fig 1. Sampling stations in the North Frisian Wadden Sea. $\mathrm{H}=$ Heverstrom, N.h. = Norderhever, S.a. = Suderaue

after the catch and kept in water filled buckets (10 l) prior to examination. The entire body of the fishes was most carefully viewed for macroscopical injuries to skin and fins.

The statistical significance of the differences between injury rates in different geographical regions as well as before and after the sieving procedure on a traditional shaking sieve (Boddeke 1989) was tested (Mann-Whitney test; Lozán 1992). The influence of fish length, haul duration and catch volume on the injury rate was determined by means of the coefficient of correlation (Sachs 1984).

After typical fishery-induced wounds had been qualitatively examined their healing process was examined. Twelve dab (12.9 to $25.3 \mathrm{~cm}$ ) were obtained from a small commercial shrimp trawler. They were held in circulation tanks supplied with North Sea water (aquarum diameter $150 \mathrm{~cm}$ ). Temperature varied from 16.7 to $19.8^{\circ} \mathrm{C}$. Oxygen supply remained above $6.5 \mathrm{mg}$ $1^{-1}(84 \%)$. All fish were acclumatızed for $5 \mathrm{~d}$, and then 4 small surgical wounds were made on each of them. The fish were anaesthetized with MS-222 (50 $\left.\mathrm{mg} \mathrm{l}^{-1}\right)$. An incision was made on the upper side of the trunk by means of a scalpel, and 3 scales were removed by forceps. The skin between 2 fin rays was lacerated (fissure) and half of a fin ray was dissected. The healing process was macroscopically studied under a stereo- microscope $(63 \times$ to $320 \times)$ while fish were anaesthetized (MS-222). Times of examination and photographic documentation were $2,12,36,48 \mathrm{~h}, 3,5,7,10$ and $13 \mathrm{~d}$ post wounding ( $\mathrm{pw}$ ). The healing process was also studied histologically. The results presented here will be limited to macroscopical findings as microscopical observations essentially confirmed the known process of healing and regeneration.

\section{RESULTS}

Catchung and sieving on a traditional shaking sieve caused skin unjuries. Wounds were not specific to either of these procedures. Injuries are described in the section below. If statistical analysis was possible, quantitative evaluation is included, followed by the results of the healing experiments. Skin injuries on the trunk had a poor reproducibility. In contrast to fissures and hemorrhages of the fins, the low frequency of broken fin rays did not allow statistical analysis. For this reason, only a qualitative description can be given for these wounds. Samples from differently composed catches could not be compared, as other parameters (area, haul duration, volume) varied too much.

Incisions, lost scales and fissures of the fins produced no typical scars which would have allowed the quantification of formerly suffered injuries. Regeneration of a lost fin ray exceeded the investigation period of $13 \mathrm{~d}$.

\section{Scratches}

Scratches on the skin or abrasions with a diameter of up to $1 \mathrm{~cm}^{2}$ could be detected all over the body. They were more prominent on the coloured upper side. Expermentally induced scratches were filled with exudate $2 \mathrm{~h}$ pw. After $13 \mathrm{~d}$, the injury was no longer visible.

\section{Loss of scales}

In contrast to a regular scale cover, many of the dab unvestıgated had crescent shaped holes in their skin. Irregularities of the scale cover were classified into 3 categories: 0 = regular cover (Fig. 2), 1 = partly irregular, 2 = crescent shaped holes over an extended area (Fig. 3).

Before sieving, dab were evenly distributed among categorles 0 to 2 (Table 1). After sieving, $92 \%$ were

Flgs 2 to 5 Limanda limanda. Fig. 2 Regular scale cover on the trunk. Scale bar $=1 \mathrm{~cm}$ Fig. 3 . Irregular scale cover on the trunk. Scale bar $=1 \mathrm{~cm}$ Fig. 4. Skın lesion from removed scale, $2 \mathrm{~h}$ pw. Scale bar $=1 \mathrm{~mm}$ Fig. 5. Skin lesion from removed scale, $3 \mathrm{~d}$ pw. Scale bar $=1 \mathrm{~mm}$ 

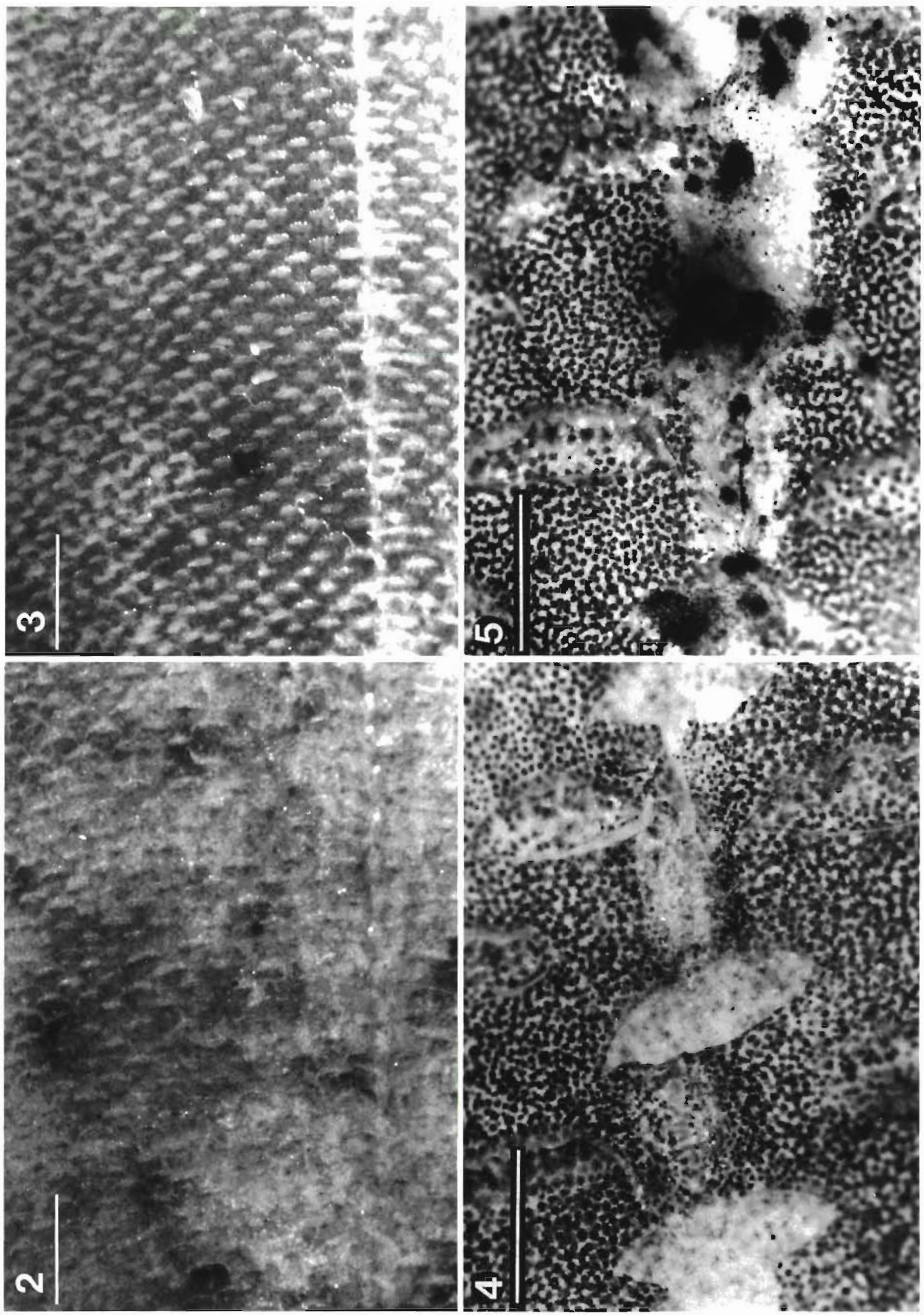
Table 1. Limanda limanda. Irregularities of scale cover before and after sorting on a shaking sieve in \% of number of examined dab

\begin{tabular}{ccc|}
\hline $\begin{array}{c}\text { Category of } \\
\text { scale cover }\end{array}$ & $\begin{array}{c}\text { Before } \\
\text { sieving } \\
(\mathrm{n}=162)\end{array}$ & $\begin{array}{c}\text { After } \\
\text { sieving } \\
(\mathrm{n}=25)\end{array}$ \\
\hline 0 & 42 & 4 \\
1 & 30 & 4 \\
2 & 28 & 92 \\
\hline
\end{tabular}

Table 2. Limanda limanda. Irregularities of scale cover from different geographical regions (see Fig. 1) in \% of number of examined dab

\begin{tabular}{|ccc|}
\hline $\begin{array}{c}\text { Category of } \\
\text { scale cover }\end{array}$ & $\begin{array}{c}\text { Heverstrom/ } \\
\text { Norderhever } \\
(\mathrm{n}=112)\end{array}$ & Süderaue \\
$(\mathrm{n}=50)$
\end{tabular}

graded category 2. The frequency of irregular scale cover also differed regionally. In the Heverstrom and Norderhever region the largest part of the dab fell into category 0 , whereas those from the Suderaue region were categorized mostly as 2 (Table 2).

In healing experiments, crescent shaped holes were caused by mechanically removing scales (Fig. 4). At $3 \mathrm{~d}$ pw a dark pigmentation (Fig. 5) indicated the onset of healing in dermal regions and allowed a clear separation between fresh and healing injuries.

\section{Fissures}

Lacerated wounds (fissures) in the fins were most prominent, and were up to $2 \mathrm{~cm}$ deep. The number of fissures per fish correlated positively with fish length (Fig. 6), catch volume (Fig. 7), and sieving procedure (Table 3). In the laboratory experiments, the edge of a fissure was covered with newly formed epidermis $12 \mathrm{~h} \mathrm{pw}$. The new epidermis grew and filled the whole laceration by $10 \mathrm{~d} p w$

\section{Hemorrhages}

Internal bleeding (hemorrhages) with a diameter of up to several millimeters was frequently visible under the skin of trunk and fins. Only hemorrhages above a diameter of $1 \mathrm{~mm}$ were counted, even though very small hemorrhages (petechiae) were numerous. The number of hemorrhages per fish correlated negatively

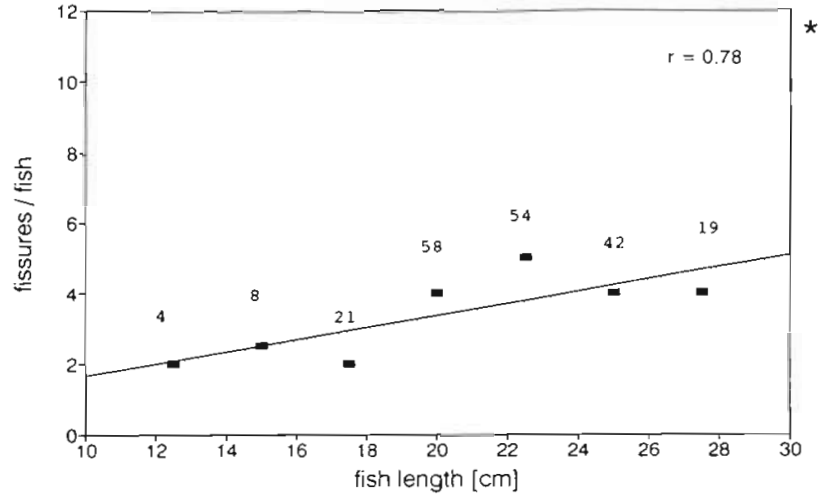

Fig. 6. Limanda limanda. Influence of fish length on the rate of fissures, expressed as linear regression for the median of every $2.5 \mathrm{~cm}$ class. $\mathrm{n}$ : number of fish examined; "significant, $\alpha<0.05$

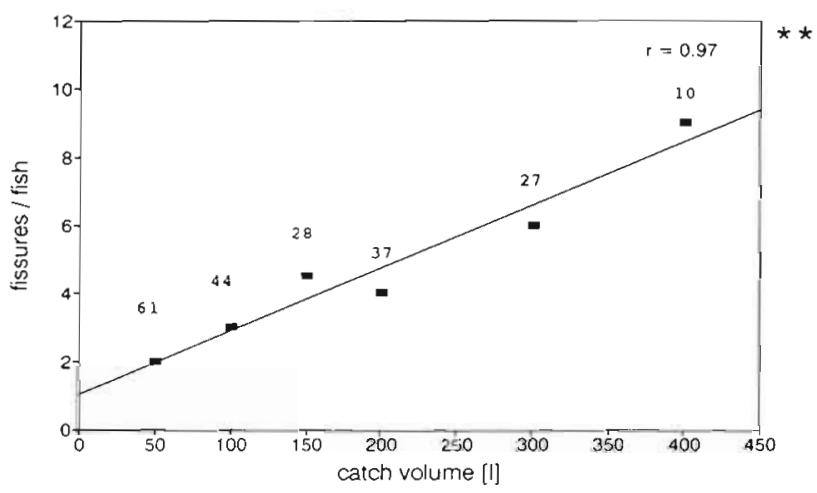

Fig. 7. Limanda limanda. Influence of catch volume on the rate of fissures, expressed as linear regression for the median of every $50 \mathrm{l}$ subsample. n: number of fish examined; " significant, $\alpha<0.01$

with catch volume (Fig. 8). It increased significantly after sieving (Table 3 )

\section{Broken fin rays}

Fin rays were fractured at different lengths after the catch processing. In most cases, less than the distal third of the fin ray was lacking. Experimentally dissected parts of the fin ray were replaced by only a narrow edge of regenerated tissue $13 \mathrm{~d}$ pw.

\section{DISCUSSION}

There are various injuries which can be attributed to fishing activity. Even small shrimp trawlers, towing at a speed of about 2 knots and yielding only relatively small catch volumes, have harmful effects on by-catch organisms. Considering the significant increase of fis- 
Table 3. Limanda limanda. Number of fin injuries per fish before and after sorting on a shaking sieve. Quart.: range between lower and upper quartiles; "significantly different, $\alpha<0.05$

\begin{tabular}{|c|c|c|c|c|c|c|}
\hline \multirow[t]{2}{*}{ Kind of injury } & \multicolumn{3}{|c|}{ Before sieving } & \multicolumn{3}{|c|}{ After sieving } \\
\hline & $n$ & Median & Quart. & n & Median & Quart. \\
\hline Fissures & 74 & 2.5 & $1-6$ & 36 & 10 & $6.5-16.5^{\circ}$ \\
\hline Hemorrhages & 106 & 2 & $0-6$ & 52 & 5.5 & $2-15.5^{\circ}$ \\
\hline
\end{tabular}

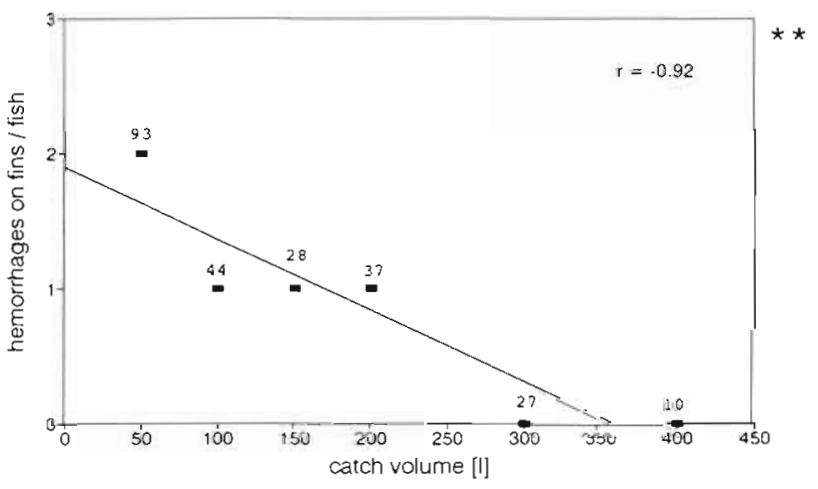

Fig. 8. Limanda limanda. Influence of catch volume on the rate of hemorrhages, expressed as linear regression for the median of every $50 \mathrm{l}$ subsample. $\mathrm{n}$ : number of fish examined - significant, $\alpha<0.01$

sures with increasing catch volume and increasing fish length, it may be assumed that more powerful trawlers will cause even more severe injuries.

Mechanical treatment during catching destroys the protective layer of the skin for a period of several hours to days, until regenerating epidermis covers the injured area (Bereiter-Hahn 1986). Internally destroyed blood vessels cause hemorrhages and petechiae in the subdermal connective tissue as well as in the brain. Kelle (1977) attributed hemorrhages in the brain to a lack of oxygen since the increasing blood pressure produces ruptures in the blood vessels. Moller \& Anders (1983) assumed hemorrhages under the skin to be caused by the weight of the catch which made blood vessels burst. This interpretation seems to be contradicted by the highly significant negative correlation between the number of hemorrhages and catch volume in this study. However, the voluminous catches in the present study which led to low rates of hemorrhages contained exceptionally few molluscs and empty shells. Thus, the amount of hemorrhages may be influenced by catch composition rather than catch volume. A high percentage of soft-bodied organisms in the net may even provide a protection against internal bleeding. In the present study, it was not possible to prove this hypothesis statistically, because differently composed catches also varied strongly in other abiotic parameters. Nevertheless, the significant increase of fissures in samples from larger catches supports the assumption that by-catch organisms can cause open wounds. Once the skin between 2 fin rays is lacerated, the fissure can easily become deeper during handling. Complete healing of a fissure requires about $10 \mathrm{~d}$. In conclusion, the effect of increasing catch volumes is considered to be serious, in spite of the decreasing rate of hemorrhages, since the number of fissures increases significantly

Open wounds imply the risk of secondary infection. Olsen (1958) stated that lymphocystis tumours in Stizostedion v. vitreum were often present in the area where scale samples had been taken. Tempelmann (1965) also found that infection by the lymphocystis virus may be greatly facilitated by injuries to the skin. Injuries to the fins may increase infections by widespread bacteria such as Vibrio, Aeromonas or Pseudomonas which are suspected to cause fin-rot disease (Schäperclaus 1979). Möller \& Anders (1983) assumed that fin-rot disease may start from wounds that are induced by nets, parasites or other damaging factors. Mellergaard \& Nielsen (1990) regard skin ulcers of dab in the open sea primarily as the result of mechanical skin damage caused by fishing gear.

Dab are known to have higher rates of skin diseases than other flatfish species (van Banning 1987). In the Wadden Sea, disease rates of $1.2 \%$ in sole Solea solea (L.), $2.5 \%$ in plaice Pleuronectes platessa L. and $6.8 \%$ in dab were found, taking into account all externally visible diseases (Anders \& Möller 1991). Dab have a rough skin with ctenoid scales. This type of scale has spines on its free posterior edge (Harder 1957). As the scales are embedded in a dermal scale pocket and covered with epidermis, the removal of a scale leads to a crescent shaped skin defect. Dab integument seems to be more susceptible to skin injuries and diseases than that of other flatfish species with cycloid scales. This could explain the correlation of irregular scale cover with high rates of externally visible skin diseases e.g. in the Süderaue region (Lüdemann 1992). As fishing intensity in this particular region is low, the fish had most likely been affected already by the intense sole fishery in the North Sea in 1992 (Will 1992) from where they had immigrated into the Wadden Sea as part of their annual migration pattern (Bohl 1957). 
According to the present investigation as well as to findings of Kelle (1977) for plaice, haul duration has no effect on the number of skin injuries. In contrast, mortality rates of flatfish increase with haul duration (Kelle 1976). This was also reported for 0-group plaice by Berghahn et al. (1992). The fact that haul duration significantly increases mortality but has no effect on injury rates supports the view that mortality of fish is not caused by external injuries. Kelle (1977) was able to show that stress followed by reduced respiration was the main reason for high mortalities.

The number of injuries increased significantly in dab which had been sorted out on a shaking sieve. Increased injury and mortality rates after the sieving procedure have also been reported by Kelle (1977) and Waltemath (1990). Consequently, the shaking sleve is very harmful to by-catch organisms. A rotary sieve, in which the by-catch is more or less washed out during the sorting procedure, may be considered an alternative (Berghahn et al. 1992).

Acknowledgements. I am grateful to the late Prof. Dr Gabriele Peters who developed the idea of this study. Thanks are also due to Dr R. Berghahn for critical review of earlier versions of this manuscript, Dr B. Watermann for much valuable advice, the staff of Littoral Station of the 'Biologische Anstalt Helgoland' where I performed the experimental studies, and the fishermen $\mathrm{C}$. Herpel and M. Mommensen. Parts of the study were supported by the Federal Environmental Agency, Environmental Research Plan of the Minister for the Environment, Nature Conservation and Nuclear Safety of the Federal Republic of Germany (Grant 10802 085/21), and by the state of Schleswig-Holstein. This is publication no. 75 of the project Ecosystem Research Wadden Sea.

\section{LITERATURE CITED}

Anders, K., Möller, H. (1991). Epidemiologische Untersuchungen von Fischkrankheiten im Wattenmeer. Ber. Inst. Meeresk. Kiel 207

Bell, G. R., Bagshaw, J. W. (1985). Observations on the fate of experimentally induced wounds on the adult chinook salmon in sea water. Can. Tech. Rep. Fish. Aquat. Sci. 1369

Bereiter-Hahn, J. (1986). Epidermal cell migration and wound repair. In: Bereiter-Hahn, J., Matoltsy, A. G., Richards, K. S. (eds.) Biology of the integument, Vol. 2, Vertebrates. Springer Verlag, Berlin, p. 443-471

Berghahn, R., Waltemath, M., Rijnsdorp, A. D. (1992) Mortality of 0-group plaice from the by-catch of shrimp vessels in the North Sea. J. appl. Ichthyol. 8: 293-306
Boddeke, R. (1989). Management of the brown shrimp (Crangon crangon) stock in Dutch coastal waters. In: Caddy, J. F. (ed.) Marine invertebrate fisheries: their assessment and management. Wiley \& Sons Press, Chichester, p. 35-62

Bohl, H. (1957). Die Biologie der Kliesche (Limanda limanda L.) in der Nordsee. Ber. dt. Wiss. Komn Meeresforsch. 15 $1-57$

Dethlefsen, V., Watermann, B., Hoppenheit, M. (1987). Diseases of North Sea dab (Limanda limanda L.) in relation to biological and chemical parameters. Arch. FischWiss. 37: 107-237

Grizzle, J. M., Chen, J., Wiliams, J. C., Spano, J. S. (1992). Skin injuries and serum enzyme activities of channel catfish (Ictalurus punctatus) harvested by fish pumps Aquaculture 107: 333-346

Harder, W. (1957). Anatomy of fishes, Part I: Text, Part II Figures and plates. E. Schweizerbart'sche Verlagsbuchhandlung (Nägle u. Obermiller), Stuttgart

Iger, Y., Abraham, M. (1990). The process of skin healing in experimentally wounded carp. J. Fish Biol. 36: 421-437

Kelle, W. (1976). Sterblichkeit untermaßiger Plattfische im Beifang der Garnelenfischerei. Meeresforsch. 25: 77-89

Kelle, W. (1977). Verletzungen untermaßiger Plattfische in der Garnelenfischerei. Arch. FischWiss. 28: 157-171

Loeb, L. (1898). Über die Regeneration des Epithels. Arch Entw.mechan. 6

Lozán, J. L. (1992). Stateasy - Statistisches Computerprogramm für wissenschaftliche Arbeiten, Version 2.01

Lüdemann, K. (1992). Fangbedingte Hautverletzungen bei Plattfischen in der Garnelenfischerei des Wattenmeeres. Dipl.-Arb. (thesis), Univ. Hamburg

Mellergaards, S., Nielsen, E. (1990). Fish disease investigations in Danish coastal waters with special reference to the impact of oxygen deficiency. Comm. Meet. int. Coun. Explor. Sea C.M.ICES E: 6 (mimeo)

Möller, H., Anders, K. (1983). Krankheiten und Parasiten der Meeresfische. Verlag Heino Möller, Kiel

Olsen, D. E. (1958). Statistics of a walleye sport fishery in a Minnesota lake. Trans. Am. Fish. Soc. 87: 52-72

Sachs, L. (1984). Angewandte Statistik. Springer Verlag, Berlin

Schäperclaus, W. (1979). Fischkrankheiten, Teil 1. AkademieVerlag, Berlin

Tempelmann, W. (1965). Lymphocystis disease in American plaice of the Eastern Grand Bank. J. Fish. Res. Bd Can. 22: $1345-1356$

Tiews, K (1990). 35-Jahres-Trend (1954-1988) der Häufigkeit von 25 Fisch- und Krebstierbeständen an der deutschen Nordseeküste. Arch. FischWiss. 40: 39-48

van Banning, P. (1987). Long-term recording of some fish diseases using general fishery research surveys in the south-east part of the North Sea. Dis. aquat. Org. 3: 1-11

Waltemath, M. (1990). Untersuchungen am Beifang der Garnelenfischerei. Dipl. Arb. (thesis), Univ. Kiel

Will, K. R. (1992). Die deutsche Seezungenfischerei seit Einführung der Quotierung. Das Fischerblatt 1:4-12 